DOI 10.15290/cnisk.2021.01.10.03

\author{
PAWEŁ WOŚ \\ https://orcid.org/0000-0003-3346-1674 \\ Uniwersytet Jana Kochanowskiego w Kielcach
}

\title{
Maria Wysłouchowa - redaktorka, publicystka, działaczka społeczna i polityczna ${ }^{1}$
}

\begin{abstract}
Streszczenie
Maria Wysłouchowa to jedna $z$ najwybitniejszych polskich działaczek politycznych ruchu ludowego, kulturowego i kobiecego na przełomie XIX i XX w. Autorka wielu utworów o tematyce historycznej, tłumaczka i popularyzatorka literatury słowiańskiej. Większość życia poświęciła redagowaniu czasopism społeczno-literackich, które stanowiły pomost pomiędzy inteligencja lwowska a nieuświadomionymi warstwami chłopskimi. Wysłouchowa swoimi dążeniami wyznaczała drogę ku demokratyzacji życia publicznego w Galicji.
\end{abstract}

Słowa kluczowe: Maria Wysłouchowa, Lwów, Galicja

\footnotetext{
Publikacja przygotowana/finansowana w ramach programu Ministra Nauki i Szkolnictwa Wyższego pod nazwa DIALOG w latach 2019-2021. Jest wynikiem udziału w projekcie badawczym pt. „Ośrodek badań historii kobiet”, nr 0016/DLG/2019/10.
} 


\title{
MARIA WYSLOUCHOWA - A REDACTOR, PUBLICIST, SOCIAL AND POLITICAL ACTIVIST
}

\begin{abstract}
Maria Wysłouchowa was the most distinguished Polish political activist of people's, cultural and female movement in 19th and 20th century. She is the author of many historical works, a translator and popularizer slavic literature. Most part of her life she spent on editing socio-literary magazines which comprised a tie between Lviv intelligentsia and unaware peasants. Wysłouchowa's endeavours set a way to democratization public life in Galicia.
\end{abstract}

Keywords: Maria Wysłouchowa, Lviv, Galicia

\section{Wstęp}

Problematyka kobieca w ostatnich latach stała się tematem, który skupił uwage licznego grona badaczy. Świadomość podejmowania coraz nowszych wątków z zakresu tematyki kobiecej sprawia, że niniejsza próba syntetycznego ujęcia pozycji i roli społecznej jednej $z$ czołowych przedstawicielek galicyjskiego ruchu ludowego w pełni wpisuje się w dotychczasowy stan badań2. Obowiazzujący materiał badawczy, rozszerzony o nowe dokumenty źródłowe, $z$ uwagi na wieloaspektowość problemu skłania do wnikliwej analizy i reinterpretacji istniejacego stanu wiedzy w kontekście aktywności oświatowej i społecznej Marii Wysłouchowej ${ }^{3}$.

2 Dobrochna Kałwa, „Ze studiów nad historią kobiet w XIX wieku. Metodologia, stan badań”, Historyka, t. 27, 1997, 123-124; Dobrochna Kałwa, Tomasz Pudłocki (red.), Historia zwyczajnych kobiet $i$ zwyczajnych mężczyzn: dzieje społeczne $w$ perspektywie gender, (Przemyśl: Państwowa Wyższa Szkoła Wschodnioeuropejska: Towarzystwo Przyjaciół Nauk, 2007); Aneta Skóra, „Rola polskiej kobiety w życiu społecznym epoki pozytywizmu w świetle opracowań, pamiętników i wspomnień”, w: Krzysztof Jakubiak (red.), Partnerka, matka, opiekunka. Status kobiety $w$ dziejach nowożytnych od XVI do XX wieku, (Bydgoszcz: Wydawnictwa Uczelniane Wyższej Szkoły Pedagogicznej, 2000).

3 Dotychczas ukazała się opowieść biograficzna o Marii Wysłouchowej autorstwa Dionizy Wawrzykowskiej-Wierciochowej. Wysłouchowa stała się także tematem artykułów Petera Brocka, natomiast jej działalność na polu redakcyjnym stała się przedmiotem zainteresowań Zofii Sokół, Zofii Kucharskiej oraz Jerzego Myślińskiego. Ważny materiał na temat życia Marii zawarty został w tomie autorstwa Wandy Daleckiej pt. Marja Wysłouchowa: wspomnienia pozgonne, (Lwów 1905), który ukazał się tuż po jej śmierci. Por. Dioniza Wawrzykowska-Wierciochowa, Wysłouchowa, (Warszawa: Ludowa Spółdzielnia Wydawnicza, 1975); Peter Brock, „Maria Wysłouchowa (1858-1905) and the Polish Peasant Movement in Galicia”, Canadian Slavonic Papers, nr 1, 2015, 89-102; Zofia Sokół, „Zorza Marii Wysłouchowej 
Podstawę źródłowa w badaniach nad Marią Wysłouchowa stanowia zbiory Zakładu Narodowego im. Ossolińskich we Wrocławiu. Przechowywana w zbiorach rękopiśmiennych spuścizna Marii, szerzej znana jako Papiery Marii i Bolesława Wysłouchów, pozwala na przybliżenie nie tylko sylwetki samej Marii, ale w równym stopniu losów biograficznych wielu innych polskich działaczek i działaczy społecznych i politycznych przełomu XIX i XX wieku. Zasadniczym trzonem zbioru jest korespondencja Marii Wysłouchowej z lat 1885-1905, obejmujaca 17 sygnatur archiwalnych. Zawiera listy adresowane przez różne osoby zarówno $z$ Galicji, jak i Królestwa Polskiego. Wśród korespondentów Marii Wysłouchowej znajdują się m.in.: Gabriela Balicka-Iwanowska, Felicja Boberska, Zofia Bouffałowa, Andrzej Galica, Eliza Orzeszkowa, Maria Siedlecka, Maciej Szarek i inni. Korespondencja obejmuje setki listów adresowanych do Marii i przez nia pisanych. Szczególne miejsce w spuściźnie stanowia jej listy do męża Bolesława Wysłoucha $z$ lat 1884-1885. Co ciekawe, listy maja charakter swoistego dziennika, skrupulatnie oddającego niemal każdą godzinę rozłąki małżonków.

Korespondencja Marii Wysłouchowej stanowi cenne źródło do badań biograficznych, tym bardziej że działaczka nie pozostawiła po sobie wspomnień ani pamiętników. Znalazła się za to na kartach pamiętników takich osobistości życia politycznego w Galicji, jak Ludwik Krzywicki, Jan Stapiński czy Bolesław Limanowski.

Spuściznę Wysłouchowej uzupełniaja materiały ze zbiorów Biblioteki Jagiellońskiej, w których lwią część stanowi korespondencja Marii z Władysławem Orkanem z lat 1893-1904. Listy te i odpowiedzi na nie, pisane na gorąco, pod wpływem wydarzeń, stanowią ważne i cenne źródło do dziejów czasopism w Polsce, a w szczególności „Przodownicy” i „Zorzy”. Przydatna okazała się również korespondencja Marii Konopnickiej z Wysłouchami.

Zbiory lwowskie również mają znaczenie badawcze. Centralne Państwowe Historyczne Archiwum Ukrainy we Lwowie obejmuje nieodkryte dotąd dokumenty poświadczające zaangażowanie Marii w działalność Towarzystwa Demokratycznego Polskiego oraz powstałego w 1895 r. Stronnictwa Ludowego. Korespondencja Marii

(1900-1902)", Kwartalnik Historii Prasy Polskiej, R. XXIII, nr 3, 1984, 53-70; Zofia Kucharska, „Kontakty Marii Wysłouchowej z ludnością Śląska Cieszyńskiego”, Śląski Kwartalnik Historyczny Sobótka, t. 29, nr 1, 1974, 67-74; Jerzy Myśliński, „Wysłouchowie: twórcy prasy ludowej”, Kwartalnik Historii Prasy Polskiej, R. XXX, nr 3-4, 145-152. 
z czołowymi przedstawicielami Stronnictwa, Karolem Lewakowskim, Jakubem Bojko czy Janem Stapińskim, jak również liczne broszury, przemówienia pisane dla męża lub, co ciekawe, program Stronnictwa Ludowego poświadczają zaangażowanie Wysłouchowej w sprawy politycznego uświadamiania chłopów. Większość dokumentów o charakterze źródłowym, zgrupowanych w zespole $\mathrm{nr}$ 841, znajdujacych sie w zbiorach lwowskiego archiwum dotyczy aktywności Marii na polu społecznym, głównie jej działań na rzecz towarzystw kobiecych, których była członkiem. Znaczna część tych źródeł to dokumenty z zebrań kół i towarzystw, które własnoręcznie protokołowała jako sekretarz.

Pozornie tylko jednostkowy wymiar prywatnej korespondencji Wysłouchowej może stać się punktem wyjścia do szerszych rozważań nad losami działaczek społecznych na przełomie XIX i XX wieku, które postrzegać można w różnych kontekstach ich politycznej, społecznej i kulturalnej aktywności, a wreszcie też codziennej i prywatnej strony życia. Pozwala także na rozpoznanie czynników i cech, które określały próby politycznego uświadomienia i pobudzenia ludności wiejskiej. Korespondencja Wysłouchowej pozwala się także przyjrzeć relacjom panującym w ruchu ludowym w obliczu powołania Stronnictwa Ludowego. Korespondencja daje więc podstawę do wielu pytań badawczych i refleksji. Listy nacechowane subiektywnym oglądem rzeczywistości staja się interesującym przekazem o życiu, o postrzeganiu świata, wartościach, uczuciach czy wreszcie politycznych poglądach autorów korespondencji.

\section{Życiorys}

Maria Wysłouchowa to jedna $z$ najwybitniejszych działaczek politycznych ruchu ludowego, oświatowego i kobiecego na przełomie XIX i XX w. Pisała utwory o tematyce historycznej i prace ludoznawcze (poświęcone Śląskowi Cieszyńskiemu i Tatrom), redagowała czasopisma społeczno-literackie dla ludu, była również tłumaczką i popularyzatorka literatur słowiańskich. Jest autorka wydanych w formie książkowej szkiców literackich o życiu i twórczości Adama Mickiewicza, Teofila Lenartowicza, Seweryna Goszczyńskiego, Kornela Ujejskiego. Oprócz tego publikowała w czasopismach sporo drobnych szkiców na temat innych znanych poetów i pisarzy, a także bohaterów narodowych (głównie dowódców woj- 
skowych). Badania prowadzone przez Irenę Bryll pokazały, jak bogaty jest dorobek pisarski Wysłouchowej. Bibliografia prac autorki Opowiadania Bartosza o Polsce liczy bowiem 253 prace (broszury, artykuły, recenzje, opracowania) oraz 30 różnego typu przekładów. Dodajmy, że działaczka ludowa znała wiele języków, m.in. łaciński, francuski, czeski, chorwacki, rosyjski, bułgarski, serbski, łotewski, ukraiński, a częściowo również niemiecki i angielski.

Maria Wysłouchowa $z$ Bouffałów, urodzona w zubożałej rodzinie ziemiańskiej w 1858 r. w Udrejkach, na Litwie ${ }^{4}$, większa część dorosłego życia spędziła w Galicji. Zainspirowana powieścia Elizy Orzeszkowej ${ }^{5}$ przyszła nauczycielka przekonała rodziców, by wysłali ją do rządowego gimnazjum w Pskowie ${ }^{6}$. Uniwersytety w tym okresie były zarezerwowane głównie dla mężczyzn, rozpoczęła więc studia w wyższej czteroletniej szkole żeńskiej, na tzw. Kursach Bestużewskich, w Petersburgu ${ }^{7}$. Po ich ukończeniu w 1882 r. przyjechała do Warszawy, gdzie podjęła prace jako nauczycielka, początkowo na pensji Izabeli Smolikowskiej, a później Henryki Czarnockiej. Pracę nauczycielki łączyła $z$ działalnością w Kobiecym Kole Oświaty Ludowej oraz Rewolucyjnym Czerwonym Krzyżu.

\footnotetext{
$4 \quad$ Hipolit Bouffał, sędzia powiatowy, ojciec Marii, utracił stanowisko, a jego majątek został skonfiskowany. Nie doczekawszy wyroku zesłania, zmarł w wileńskim więzieniu. Część posiadłości matki naszej bohaterki, Zofii, została skonfiskowana, majątek zaś w Udrejnikach obłożono tak wielka kontrybucja, że rodzina pozostała bez środków do życia. Matka Marii, pianistka, władająca biegle językami obcymi, dorabiała jako guwernantka. Zob. Dioniza Wawrzykowska-Wierciochowa, Wysłouchowa, 8-9.

5 Powieść, o której mowa, to Marta, opublikowana na łamach „Tygodnika Mód i Powieści” w 1873 r. Pisarka kładła nacisk na kwestie kobiece, a zwłaszcza na konieczność zapewnienia kobietom dobrego wykształcenia. Maria, zafascynowana dziełami Orzeszkowej, realizowała się na polu zawodowym, początkowo jako pracowita uczennica, a po ukończeniu studiów jako nauczycielka. Współpraca Wysłouchowej i Orzeszkowej ujawniła oddanie Marii dla sprawy chłopskiej. Zdumiona jej poczynaniami Orzeszkowa posłużyła się postacią działaczki ludowej w swoich powieściach. Wanda Dalecka w 1905 pisała: „Moge jeno nadmienić, iż z pewnościa nie brała wzorów z nieba Orzeszkowa dla swoich bohaterek powieściowych, lecz musiała je spotykać na Litwie. A zaś krewna z ducha tych bohaterek (zwłaszcza Dzikiej z "Dwóch biegunów" i Seweryny z "Ad astra») wydaje mi się Marja Wysłouchowa". Pogląd Daleckiej potwierdza Wawrzykowska-Wierciochowa. Zob. Wanda Dalecka, Marja Wysłouchowa; Dioniza Wawrzykowska-Wierciochowa, Wysłouchowa, 59-60.

6 Wypowiedź Wysłouchowej do Pauliny Kuczalskiej-Reinschmit: „Gdy miałam lat 13, ukradkiem przeczytana Marta wywarła na mnie wrażenie tak potężne, że nie ustałam w prośbach i naleganiach, dopóki nie wysłano mnie na naukę do gimnazjum pomimo oburzenia całej okolicy". Zob. Edmund Jankowski, Eliza Orzeszkowa, (Warszawa: Państwowy Instytut Wydawniczy, 1988), 154-155.

7 Szkoła została założona w 1878 r. z inicjatywy grupy uczonych z Konstantym Bestużewem-Riuminem na czele. Umożliwiała pozbawionym dostępu do uniwersytetów kobietom zdobyć wyższe wykształcenie.
} 
W latach 80. XIX w. w Królestwie Polskim zaczał organizować się ruch socjalistyczny, którego centralnym ośrodkiem była Warszawa. Pierwszym liczacym się stronnictwem socjalistycznym stała się założona $z$ inicjatywy Ludwika Waryńskiego w 1882 r. Socjalno-Rewolucyjna Partia Proletariat. W działalność jej struktur zaangażowała się Zofia Bouffałowa, jednak szybko została aresztowana i zesłana na Syberię. $Z$ ruchem socjalistycznym związała się również Maria, która w tym czasie zaprzyjaźniła się z Ludwiką Wysłouchowa (Zawadzka) - jej brat, Bolesław, został uwięziony w Cytadeli Warszawskiej. Przebywajac w Cytadeli, Wysłouch postanowił wykorzystać czas pobytu w więzieniu na specjalistyczne studia. Na przeszkodzie stanęła choroba oczu, częściowa ślepota, która przybrała tak poważne rozmiary, że więźnia skierowano na konsultacje do okulistów. Rodzina Bolesława wyjednała zezwolenie władz rosyjskich na korzystanie $z$ pomocy lektorki, której obowiązki początkowo pełniła Ludwika. Upoważniona siostra mogła odwiedzać więźnia przez dwie godziny dziennie, aby czytać mu na głos. Zmienniczką Ludwiki w tych odwiedzinach została Maria. Tak doszło do pierwszego spotkania Bolesława i Marii, którzy pobrali się po zwolnieniu Wysłoucha $z$ X Pawilonu w 1884 r. $^{8}$

Wysłouch po wyjściu $z$ więzienia odczuwał silny zwiazek $z$ doktryna rosyjskich populistów, która znalazła wyraz w środowisku skupionym wokół Proletariatu. Zdawał sobie sprawę, że uczestnictwo w nielegalnych organizacjach grozi natychmiastowym aresztowaniem, a wiadomości o kolejnych aresztowaniach dzialaczy partii Proletariat utwierdzały nowożeńców w postanowieniu o opuszczeniu Królestwa Kongresowego. W Galicji mogli spodziewać się znacznie lepszych perspektyw legalnej działalności politycznej.

Wiosna 1885 r. Wysłouchowie przybyli do Lwowa. Bolesław tuż po przyjeździe czynił starania o uzyskanie obywatelstwa austriackiego. Maria nie musiała podejmować działań w tej kwestii, ponieważ według kodeksu rodzinnego żona przyjmowała obywatelstwo męża. Dzięki nawiazzaniu rozległych stosunków towarzyskich, w krótkim czasie udało się Wysłouchowi otrzymać dokument, który

\footnotetext{
8 Data ślubu nie została sprecyzowana. Jerzy Myśliński podaje, że odbył się on jesienią 1884 r. Dioniza Wawrzykowska-Wierciochowa zaś stwierdza, że małżeństwo Bolesława i Marii zostało zawarte w okresie świąt Bożego Narodzenia 1884 r. Inną datę podaje Zofia Kucharska, twierdząc, że wydarzenie miało miejsce w 1885 r. Zob. Jerzy Myśliński, „Wysłouchowie: twórcy prasy ludowej”, 145; Dioniza Wawrzykowska-Wierciochowa, Wysłouchowa, 95-96; Zofia Kucharska, „Kontakty Marii Wysłouchowej”, 68.
} 
pozwalał nie tylko na stały pobyt w Galicji, ale również na legalna działalność społeczną. Niemałą rolę w nawiązywaniu relacji towarzyskich odegrała Maria. Stało się to m.in. za pośrednictwem Wiktorii Niedziałkowskiej ${ }^{9}$, przełożonej liceum żeńskiego, w którym Wysłouchowa nauczała literatury polskiej. $Z$ kolei Bolesław nawiazywał kontakty $z$ przedstawicielami świata dziennikarzy i polityków. Znalazł się również w bliskich stosunkach $z$ kołami postępowej inteligencji demokratycznej. Skupiała się ona wokół dziennika „Kurier Lwowski”, gdzie pierwszoplanowe role odgrywali m.in. publicysta i redaktor Henryk Rewakowicz oraz polityk Karol Lewakowski.

Wysłouchowa nie brała czynnego udziału z życiu politycznym. Nie sprawowała także żadnego urzędu zarówno w administracji państwowej, jak i partyjnej. Należy jednak pamiętać, że rola Marii w galicyjskim ruchu społecznym i politycznym była znacznie ograniczona ze względów prawnych. Występowała jako żona redaktora i polityka, jako publicystka i pisarka. Zadaniem, któremu się poświęciła, było podniesienie poziomu kulturowego ludności chłopskiej, aby mogła świadomie wywierać wpływ na politykę. Maria dzięki swoim umiejętnościom pisarskim i wychowawczym, eksponujaca patriotyczna tradycję chłopska, doskonale nadawała się do kształtowania kulturowo i politycznie zacofanego chłopa na odpowiedzialnego obywatela.

Małżeństwo $z$ Bolesławem znacznie rozszerzyło zakres działalności Marii. Od początku pobytu w Galicji stała się współpracowniczką swojego męża ${ }^{10}$. W zaskakująco krótkim czasie nawiąali liczne kontakty z inteligencją lwowska, czego dowodem był sukces wydawniczy miesięcznika o ogólnym zabarwieniu politycznym. Pierwszy numer „Przegladu Społecznego”, jak zatytułowano miesięcznik, ukazał się w styczniu 1886 r. Środowisko osób współpracujących $z$ „Przeglądem Społecznym” obejmowało wiele nazwisk, dobrze znanych $\mathrm{w}$ kręgach postępowych. Jednak $\mathrm{z}$ powodu licznych konfiskat i braku wsparcia finansowego Wysłouch zaprzestał jego publikowania po osiemnastu miesiącach działalności. Pomimo krótkiego okresu istnienia i niewielkiej liczby odbiorców, ograniczonej do intelektualistów lwowskich, „Przeglądowi Społecznemu”

\footnotetext{
9 Pensja Niedziałkowskiej została założona w 1886 r. Istniała zaledwie 9 lat.

10 Ludwik Krzywicki pisał o tym następująco: „... podchwytywała jego wywody, niekiedy nadawała im charakter bojowy, co on popierał gestami, mimika twarzy". Por. Ludwik Krzywicki, Wspomnienia, t. 2, (Warszawa: Czytelnik, 1958), 108.
} 
udało się stworzyć ideologiczne podstawy przyszłego ruchu ludowego $^{11}$. Był to okres wzmożonej aktywności redakcyjnej Marii. Wyręczała męża w korespondencji, przepisywaniu artykułów po poprawkach redakcyjnych oraz korektach drukarskich. Ludwik Krzywicki, który wówczas był bliskim przyjacielem Wysłouchów odnotował:

Choć wyrozumiały w rozmowie Wysłouch sprawdził każde słowo $\mathrm{w}$ artykułach opublikowanych w Przegladzie Społecznym. Jego ołówek redakcyjny ... biegał bez ceremonii przez pomysły innych i usuwał $z$ nich nie tylko herezje, ale wszystko, co najmniej odbiega od ortodoksyjnego populistycznego „kościoła”, jak go sobie wyobrażał. A raczej robiła to jego żona, ponieważ Wysłouch miał problemy z oczami. Ale robił to $z$ większą bezwzględnością, kierując się nie tylko logika, co uczuciem. ... Maria była ślepo oddana mężowi. Był $z$ natury jednomyślny, a ona też była zdecydowana ponieważ jej mąż by ${ }^{12}$.

Maria Wysłouchowa oprócz pomocy mężowi w redakcji „Przeglądu Społecznego" rozpoczęła szeroko zakrojoną działalność dziennikarską w „Kurierze Lwowskim”, którego Bolesław był redaktorem i współwłaścicielem ${ }^{13}$. Maria nadal pełniła obowiązki lektorki

11 „Przegląd Społeczny. Pismo Naukowe i Literackie”, ukazujący się w latach 1886-1887, był wydawany i redagowany przez Wysłoucha przy pomocy żony Marii. Kierowany był przede wszystkim do środowisk inteligenckich. W pierwszym numerze zamieszczony został program miesięcznika, w którym czytamy: „Program nasz musi być ludowym, bo, po pierwsze, chce tego etyka społeczna, która dobra ogółu, interesa mas ludowych ... w działaniu społecznym uznaje, bo, po wtóre, wówczas tylko wyzwala siły uwięzione mas ludowych, które podejmą energicznie i świadomie pracę nad rozwiązaniem społecznego postępu". Do grona współpracowników zaliczyć należy m.in.: Jana Kasprowicza, Zygmunta Miłkowskiego, Iwana Franko, Bolesława Limanowskiego, Wilhelma Feldmana czy Mychajła Drahomonowa. Zob. Krzysztof Dunin-Wasowicz (red.), Przeglad Społeczny 1886-1887, (Wrocław: Zakład imienia Ossolińskich, Wydawnictwo Polskiej Akademii Nauk, 1955); idem, Czasopiśmiennictwo ludowe $w$ Galicji, (Wrocław: Wydawnictwo Zakładu Narodowego im. Ossolińskich, 1952), 69-99; Jerzy Jarowiecki, Studia nad prasa polska XIX i XX wieku, t. 2, (Kraków: Wydawnictwo Naukowe Akademii Pedagogicznej: 2006), 108-109.

12 Ludwik Krzywicki, Wspomnienia, 258-261.

13 „Kurier Lwowski” - dziennik wychodzacy od 31.03.1883 r., którego pierwszym redaktorem został Ludwik Masłowski. Rok później redakcję objął Henryk Rewakowicz, przekształcając pismo w postępowy, antystańczykowski organ prasowy. Od 1887 r. „Kurier” stał się własnością spółki: Henryk Rewakowicz, Bolesław Wysłouch i Edward Lilien. W 1907 r. Wysłouch zdecydował o kupnie dziennika, stając się tym samym jedynym właścicielem gazety. Postulaty sformułowane przez Wysłoucha na łamach "Przegladu Społecznego" zostały rozwinięte w „Kurierze Lwowskim”, którego rys programowy przedstawiono w pierwszych trzech numerach okazowych w $1883 \mathrm{r}$. Szczególna rolę odegrała w nim kwestia poprawy sytuacji materialnej najuboższych warstw, jak też sprawy własności ziemskiej i kwestii agrarnej. Wysłouch postulował równość praw i obowiazków obywateli, opowiadał się za rozwojem nauki i literatury podnoszącej poziom życia intelektualnego polskiego chłopa. Do tego celu służyły 
i sekretarki, aktywnie uczestnicząc we wszystkich pracach organizacyjnych i redakcyjnych, zasilając pismo licznymi artykułami. Działalność redakcyjna Marii nie mogła być w pełni doceniona, ponieważ ze względu na obowiązujące prawo nie mogła oficjalnie występować jako redaktor lub właściciel organu prasowego. Pomimo tych ograniczeń wielu historyków doceniło jej wkład pracy w redakcję gazet, nazywając ja „faktyczną współredaktorka”.

W niedługim czasie wytworzył się wokół Wysłoucha ośrodek polityczny. W kręgu współpracowników znaleźli się również działacze chłopscy tacy jak Jakub Bojko i Jan Stapiński. Ten ostatni, bliski towarzysz Wysłouchów i oddany działacz na rzecz ludu chłopskiego, odnotował:

Sądzę, że już w tym miejscu winienem opowiedzieć moje stosunki z Bolesławem Wysłouchem. ... Stosunek nasz wzajemny podobnym początkowo był w mym zrozumieniu do stosunku między koncypiantem adwokackim a adwokatem, albo do stosunku między starszym gospodarzem a zaczynającym gospodarkę. Starszy o 12 lat, $z$ kultura syna ziemianina polskiego, szlachcic $z$ wyższym wykształceniem ... o przekonaniach demokratycznych, cała dusza pragnacy się przyczynić do wyzwolenia ludu polskiego z ciemnoty, nędzy i poniżenia społecznego ... Wróg trunków alkoholowych, abstynent od wszelkich zabaw, domator o bardzo skromnej skali wymagań, żonaty z Maria - idealistka, działaczką społeczną i partiotka-entuzjastka najszlachetniejsza, o idealnie czułym sercu dla niedoli ludzkiej, znakomita autorką mnóstwa książek $z$ historii polskiej i artykułów popularnych, mówczynią porywającą ${ }^{14}$.

Działalność literacka i nauczycielska nie zaspokajały ambicji Wysłouchowej. Podobnie jak Bolesław pragnęła w sposób bezpośredni oddziaływać na chłopów. Posłużyć temu miało powołanie do życia nowego przedwsięwzięcia, które wyraziłoby potrzeby chłopstwa. W takich okolicznościach 1 kwietnia 1889 r. pod redakcja

\footnotetext{
wydawane na łamach gazety w odcinkach powieści i pamiętniki, polskich i zagranicznych autorów. W początkowym okresie istnienia „Kuriera Lwowskiego” odwoływał się on przede wszystkim do galicyjskiego drobnomieszczaństwa, aby w kolejnych latach działalności publicystycznej rozszerzyć obszar oddziaływania na inteligencję ludowa i sympatyków powstającego ruchu ludowego. „Kurier”, redagowany przez Wysłoucha i jego żonę Marię z Bouffałów, wyróżniał się na tle dziennikarstwa galicyjskiego. Reprezentował tendencje demokratyczne, podtrzymujące tradycje niepodległościowe. Świadczyć o tym moga chociażby obszerne relacje $z$ obchodów rocznic powstania styczniowego.

14 Jan Stapiński, Pamiętnik, (Warszawa: Ludowa Spółdzielnia Wydawnicza, 1959), 121-122.
} 
Wysłoucha ukazał się pierwszy numer „Przyjaciela Ludu”15. W miejsce dotychczasowych pism o charakterze moralizatorskim przeznaczonych dla ludu, pojawił się nowy typ pisma ludowego, w którym czynny udział mieli brać chłopi. Andrzej Paczkowski do najbardziej charakterystycznych cech, zarówno „Przyjaciela Ludu”, jak i „Kuriera Lwowskiego”, zaliczył współredagowanie ich przez chłopskich czytelników. Owo współdziałanie odbywało się dzięki nadsyłaniu do redakcji „listów-próśb, listów-skarg, listów-deklaracji politycznych, listów-informacji". Listy te wypełniały gazety ludowe, a do nich dochodziły teksty działaczy politycznych, społecznych, gospodarczych powiąanych $z$ organizacjami wiejskimi ${ }^{16}$.

Maria miała niebagatelny wpływ na redakcję zarówno „Kuriera Lwowskiego”, jak i „Przyjaciela Ludu”. Na łamach gazety ukazała się seria artykułów poświęconych popularyzacji dziejów Polski, a zwłaszcza takich wydarzeń, które podkreślały patriotyzm chłopów. Szczególna jej aktywność przypadła na lata 1890-1894, kiedy obie gazety stale poruszały kwestie oświatowe. Liczne artykuły, które wzywały do zakładania czytelni ludowych, przypisuje się autorstwu Wysłouchowej. Okres wielkich rocznic narodowych stawał się pretekstem dla Marii, aby zamieszczać na łamach gazet teksty poświęcone powstaniom narodowym. Dużo miejsca poświęcała również opisom Kujaw i Śląska lub miejscowościom takim jak Poznań czy Kruszwica. Dzięki jej staraniom współpracę z ludowymi organami prasowymi nawiązali późniejsi działacze ruchu chłopskiego, jak M. Szarek, Franciszek Krempa, Franciszek Wójcik i inni.

Wysłouchowa w poczatkowym okresie pobytu w Galicji zajmowała się nie tylko praca redaktorską, ale również aktywnie działała na rzecz tworzacych się instytucji ruchu kobiecego. W 1886 r. powołano do życia Czytelnię Naukową dla Kobiet, której za nadrzędny cel postawiono stworzenie ogniska życia intelektualnego i ożywienie ruchu umysłowego kobiet. W Czytelni odbywały się spotkania zarówno $z$ działaczami kulturalnymi i naukowymi, jak

\footnotetext{
15 Właściwym redaktorem „Przyjaciela Ludu” był Bolesław Wysłouch, jednak ponieważ nie miał obywatelstwa, pierwszym redaktorem został drukarz i powstaniec z $1863 \mathrm{r}$. Jan Mittig. Od 1890 r. Bolesław jako prawny obywatel austriacki mógł sygnować pismo swoim nazwiskiem. „Przyjaciela Ludu” łączył ścisły związek z „Kurierem Lwowskim”, ponieważ administracja tego drugiego zarządzała jednocześnie obydwiema gazetami.

16 Andrzej Paczkowski, Prasa polityczna ruchu ludowego (1918-1939), (Warszawa: Państwowe Wydawnictwo Naukowe, 1970), 23.
} 
i politykami ${ }^{17}$. We Lwowie powołano w ten sposób pierwsze ogniwo łączące tajną organizację Koło Kobiet Korony i Litwy z emancypacyjnymi placówkami lwowskimi. W realizacje tego projektu zaangażowana była, oprócz Stefanii Wekslerowej, Maria Wysłouchowa.

$Z$ inicjatywy Marii 18 listopada 1886 r. zostało utworzone Towarzystwo Oszczędności Kobiet ${ }^{18}$. Z siedziba we Lwowie przy ul. Batorego 1. $11^{19}$, „zawiazało się w gronie niewiast naszych, jako bodziec do oszczędności, ułatwiającej ofiarność patryotyczną"20. Pośród szeroko zakrojonej działalność społecznej i oświatowej w Galicji Towarzystwo usiłowało pomóc polskiemu Poznańskiemu Bankowi Spółdzielczemu, który zajmował się skupowaniem zadłużonych majątków szlachty wielkopolskiej, wystawionych na licytacje przez rzad pruski ${ }^{21}$. Wysłouchowa od listopada 1886 do lipca 1892 r. pełniła w Towarzystwie obowiązki sekretarki. Zofia Romanowiczówna, jedna $z$ założycielek Towarzystwa, podkreślała wkład Wysłouchowej w początkowy sukces, bowiem zaproponowany przez nią tzw. lawinowy system zbierania składek okazał się nader skuteczny ${ }^{22}$. Ponadto Maria zajmowała się pisaniem sprawozdań i listów, wysyłaniem pieniędzy dla głodujących gmin oraz organizowaniem dochodowych wydarzeń kulturalnych, takich jak loterie czy koncerty ${ }^{23}$.

Maria nie poprzestawała na działalności w TOK. Wiosna 1890 r. powołała wraz z mężem do życia Towarzystwo Przyjaciół Oświaty. Jan Stapiński w pamiętniku dał obszerną relację z działań Towarzystwa:

Wnioskodawcami założenia tego towarzystwa byli Bolesław i Maria Wysłouchowie. Ich też współpracownicy, zwolennicy i znajomi sta-

\footnotetext{
17 Centralne Państwowe Historyczne Archiwum Ukrainy we Lwowie (dalej: CPHAUL), zesp. 841, inw. 1, sygn. 151, k. 1-6. Statuta Czytelni dla kobiet we Lwowie.

18 CPHAUL, zesp. 841, inw. 1, sygn. 152, k. 14: Projekt Statutu Towarzystwa Oszczędności Kobiet.

19 CPHAUL, zesp. 841, inw. 1, sygn. 152, k. 16: Odezwa Towarzystwa Oszczędności Kobiet.

20 CPHAUL, zesp. 841, inw. 1, sygn. 152, k. 7: Sprawozdanie z czynności Towarzystwa Oszczędności Kobiet we Lwowie od dnia 18. listopada 1886 - do dnia 31. grudnia 1887.

21 Towarzystwo za oszczędzone 12 tysięcy marek pruskich zakupiło akcję powstającego banku. Kwota przeznaczona na wymieniony cel była kluczowa, ponieważ dopełniła wymagana przez rząd pruski kwotę miliona marek, bez którego nie powstałby Poznański Bank Społdzielczy. CPHAUL, zesp. 841, inw. 1, sygn. 152, k. 16: Odezwa Towarzystwa Oszczędności Kobiet wzywajaca do solidarnej pracy narodowej.

22 Zofia Romanowiczówna, Klaudynki. Kartki z dziejów patriotycznej pracy kobiet w Galicyi, $w$ drugiej połowie ubiegłego stulecia, (Lwów: Księgarnia Gubrynowicza i syna, 1913), 83.

23 Dioniza Wawrzykowska-Wierciochowa, Wysłouchowa, 151-152.
} 
nowili liczne grono członków-założycieli... Prezesem Towarzystwa został Bolesław Wysłouch, zastępca prezesa - Bronisław Deskur (sędziwy już weteran powstania 1863 roku). Towarzystwo miało wzniosły program działania i stworzenie go było bardzo na czasie. Miało ono na celu, tak samo jak „Przyjaciel Ludu”, pracę nad narodowym, obywatelskim, społecznym i gospodarczym uświadomieniem ludu miejskiego i wiejskiego w duchu postępowym, wyzwalającym z pozostałości pańszczyźnianych i inkwizycyjnych. Inaczej mówiąc TPO miało pracować dla idei walki o wyzwolenie narodu z niewoli, poczucia równości wobec praw ludzkich, zwalczania przywilejów stanowych oraz wyzysku uprawianego na chłopach i robotnikach ${ }^{24}$.

Wysłouchowa bardzo mocno zaangażowała się w popularyzowanie wśród ludu wiejskiego dzieł Adama Mickiewicza, dostarczając przy tym wielu informacji na temat jego życia i twórczości. Publikowała artykuły, rozprowadzała wśród mieszkańców prowincji wydana w 1890 r. dzięki nakładom Towarzystwa Przyjaciół Oświaty broszurę $O$ życiu i pismach Adama Mickiewicza. W 1898 r. Wysłouchowa napisała i opublikowała kolejna broszurę - Adam Mickiewicz, jego życie $i$ dzieła. Było to wydanie przeznaczone głównie dla chłopskich warstw społeczeństwa galicyjskiego. Nadmienię tylko, że Maria starała się wydobywać te elementy z twórczości Mickiewicza, które dotyczyły ludu wiejskiego, pragnąc w ten sposób zachęcić chłopów do większej ich aktywności w życiu społecznym.

Projektem, któremu Wysłouchowa poświęcała każdą chwilę była redakcja „Tygodnia”. Dodatek literacki do „Kuriera Lwowskiego” - „Tydzień” - ukazywał się we Lwowie od 2 stycznia 1893 do 30 grudnia 1906 r. Wysłouchowa poprzez systematyczne informacje o postępach myśli naukowej dążyła do uczynienia $z$ „Tygodnia” pisma podnoszacego poziom życia intelektualnego zarówno mieszkańców Lwowa, jak i całej Galicji:

Wobec tego cięży na prasie codziennej obowiązek zaznajamiania licznych stosunkowo czytelników z ważniejszymi objawami na niwie literatury i zasilania w ten sposób społeczeństwa karmą duchową, bez której obniża się nie tylko poziom umysłowości, ale i życia politycznego. ... W rozwoju myśli ludzkiej największą wartość miały zawsze te fakty, pod wpływem których formowały się

24 Jan Stapiński, Pamiętnik, 128. 
nowe pojęcia lub przeobrażały stare. W rozwoju polityczno-społecznym największa doniosłość mają i mieć będą takie fakty, od których zawisłym jest postęp, a w takich, jak nasze, warunkach - wielkie dzieło odrodzenia ${ }^{25}$.

Redakcja „Tygodnia” z Maria Wysłouchowa na czele spełniała szereg celów. Popularyzacja wiedzy historycznej wśród inteligencji miejskiej i wiejskiej poprzez liczne publikacje odnoszace się do historii Polski, teksty jubileuszowe, nowości literackie, informacje o pamiatkach narodowych, to wszystko przyczyniało się do zachowania jak największej spuścizny narodowej. Podtrzymywanie i umacnianie świadomości narodowej, kult powstań narodowych i ich bohaterów stanowiły dla Wysłouchowej wartość duchową, której nie wolno zatracić w walce o postęp i niepodległa Polskę ${ }^{26}$. W publikacjach Wysłouchowej można dostrzec idee o odzyskaniu przez Polskę niepodległości. Myśl o walce narodowej powinna być ciagle żywa, ale zbrojne wystąienie powinno zostać poprzedzone jak największym uświadomieniem polskich warstw społecznych. Dlatego owa myśl o walce przypominać miały obchody narodowe i demonstracje czy patriotyczne wychowanie domowe. Działania podejmowane przez Marię współgrały z programem wygłoszonym na łamach „Przeglądu Społecznego” przez męża Marii, Bolesława. W 1886 pisał:

Na każdym kroku słyszymy dziś poglady występujące śmiało i otwarcie przeciw szlacheckiej tradycji; młodzież zapowiada niedwuznacznie radykalny zwrot w działaniu społecznym. Podsłuchać i zrozumieć te nowy prądy, kiełkujące w społeczeństwie, nadać im formę określoną; ujać w system nowe pojęcia o ideałach i drogach pracy ideowej w Polsce; obudzić u nas ruch umysłowy, który czerpiąc wiedzę u jej źródła umiałby jednak wyciagnąć z niej wskazówki odpowiednie do potrzeb i interesów naszego kraju; zachować zgodność pomiędzy naszym ideałem narodowym a duchem czasu, tj. tymi ideałami ogólnoludzkimi, które wysuwa wiek każdy na widownię dziejów powszechnych; w ich świetle ocenić dawne ideały polskie, zmienić je i zmodyfikować tak, by stały się wyrazem prawdy społecznej ${ }^{27}$.

„Tydzień” 1893, nr 1, 1.

26 Alfred Toczek, „Problematyka historyczna w literacko-naukowym dodatku "Kuriera Lwowskiego" - "Tydzien" (1893-1906)”, Rocznik Historii Prasy Polskiej, z. 2, 2002, 78-102.

27 Bolesław Wysłouch, „Szkice programowe”, Przeglad Społeczny, t. 1, z. 2, 1886, 97. 
Zgodność pomiędzy „ideałem narodowym” a „duchem czasu” miała być zapewniona programem łączacym odbudowanie państwa $z$ równoczesną aktywizacja polityczną warstw ludowych. Można było tego dokonać poprzez demokratyzację życia publicznego. Uwaga Wysłouchów koncentrowała się zatem na chłopach, stanowiących w Galicji przytłaczajacca większość. Uświadomieni politycznie i pozyskani dla ideału odrodzenia Polski zapewniliby siłę mogąca doprowadzić naród do wolności. Tak więc wszystkie działania podejmowane przez Wysłouchowa, wystapienia publiczne oraz organizowanie towarzystw i kółek, miały na celu podniesienie świadomości narodowej Polaków, zwłaszcza chłopów. Do tego celu miały służyć również artykuły zamieszczane na łamach „Tygodnia”. Szczególnie ważne opracowania ukazywały się $z$ okazji 100-lecia powstania kościuszkowskiego (1894), 100-lecia urodzin Adama Mickiewicza (1898), 40-lecia wybuchu powstania styczniowego (1903) czy w 60. rocznicę wybuchu powstania krakowskiego (1906). Tak więc dodatek literacki „Tydzień” zajmował poczesne miejsce w czasopiśmiennictwie społeczno-kulturalnym, a także literackim ówczesnej Galicji.

Przełomowym momentem w życiu Marii był I Zjazd Kobiet w Zakopanem 15 sierpnia 1899 r. Wysłouchowa wystapiła z referatem „O kobiecie wiejskiej jako dziewczynie, żonie, matce, pracownicy i obywatelce", w którym nakreśliła obraz społecznego uciemiężenia kobiet. Podczas zjazdu wystapiono z propozycja wydawania pisma dla gospodyń wiejskich. Uchwała została przyjęta jednogłośnie, wraz z projektem i programem przyszłego pisma ${ }^{28}$. Redaktorem „Przodownicy”, taki miało nosić tytuł, wybrano Marię Wysłouchową. Wybrano również komitet wydawniczy, w którego skład wchodziły delegatki $z$ wszystkich trzech zaborów.

Powstanie "Przodownicy” związane było $z$ rozwijającym się w ostatnim dziesięcioleciu XIX w. ruchem ludowym, a wraz z nim z działalnością Marii Wysłouchowej i Marii Siedleckiej29. Rodzący

\footnotetext{
28 Na łamach „Kuriera Lwowskiego” opublikowano obszerną relację z zakopiańskiego zjazdu, podając program „Przodownicy”. Głównym zadaniem pisma było rozniecanie miłości ziemi ojczystej, budzenie zainteresowania dla spraw publicznych. Pismo miało kształcić czytelniczkę w zakresie zajęć wypełniajacych jej życie codzienne jako wychowawczyni i pracownicy, przede wszystkim w zakresie wychowania dzieci, a także udzielać informacji z dziedzin gospodarstwa domowego i rolnego, żywienia rodziny, przygotowania artykułów przeznaczonych na sprzedaż itd. Por. „Pierwszy zjazd kobiet polskich w Zakopanem”, Kurier Lwowski, nr 229, 1899, 1.

29 Maria Siedlecka (1856-1934) - działaczka społeczna i oświatowa, współorganizatorka Towarzystwa Szkoły Ludowej. Stała na czele Koła Pań Towarzystwa Szkoły Ludowej, które
} 
się ruch ludowy, podobnie jak kobiecy, postawiły sobie za cel budzenie świadomości narodowej warstw chłopskich. Siedlecka i Wysłouchowa od 1894 r., tj. od Zjazdu Pedagogicznego, rozpoczęły działalność oświatowa wśród kobiet wiejskich. Ze względu na wielowiekowe tradycje dola mieszkanek wsi rysowała się w ciemnych barwach. Kobiety nie miały dostępu do organizacji społecznych ani kulturalnych. Ciemna i zabobonna masa, jaka stanowiły wiejskie kobiety, hamowała przemiany społeczno-oświatowe wśród ludności wiejskiej ${ }^{30}$.

„Przodownica” ukazywała się od 1899 r. Wysłouchowa była redaktorką numeru okazowego pisma $z$ grudnia 1899 r. oraz dwóch następnych ze stycznia i lutego 1900 r., mimo iż na łamach pisma figuruje nazwisko Marii Siedleckiej. Autorstwo Marii potwierdzaja Wspomnienia pozgonne ${ }^{31}$. Pierwsze trzy numery stały się regułą nie tylko dla przyszłych wydań pisma, ale również dla innych pism kobiecych. Numery, których redaktorką była Wysłouchowa, zawierały wiersz, powiastkę, legendy ludowe i reportaż. Maria popularyzowała wiedzę historyczną wśród czytelników, prosząc o nadsyłanie lokalnych podań i legend ludowych. Ważną częścią pisma były artykuły historyczne związane $z$ rocznicami lub aktualnymi wydarzeniami, np. z rocznicami powstań narodowych ${ }^{32}$. „Przodownica” kładła nacisk na treści patriotyczne. Pismo walczyło o zaangażowanie kobiet wiejskich w sprawy oświatowe i kulturalne, co przyśpieszyłoby przeobrażenia wsi polskiej.

Nieporozumienia co do programu, treści i kolportażu pisma w łonie redakcyjnym spowodowały odejście Wysłouchowej. Maria pragnęła „Przodownicę" powiazać z ruchem ludowym, na co nie wyrażała zgody pozostała część grona redakcyjnego. Porzucenie pisma nie zahamowało pracy Marii na rzecz wiejskich kobiet. Już od kwietnia 1900 r. zaczęła wydawać miesięcznik „Zorza”. Pismo to ukazywało się we Lwowie przez następne trzy lata. Wysłouchowa wypełniała je artykułami o tematyce historycznej, literackiej i kra-

stało się pierwszym kobiecym stowarzyszeniem w Galicji. Pod jej przewodnictwem powstała w Krakowie Czytelnia dla Kobiet. W 1894 r. brała udział w Kongresie Pedagogicznym odbywającym się we Lwowie, gdzie poznała Marię Wysłouchową. Przewodnicząca I Zjazdu Kobiet w Zakopanem.

30 Zofia Sokół, "Przodownica" (1899-1912). Zarys monograficzny”, Rocznik Naukowo-Dydaktyczny WSP, z. 1, 1982, 99-123.

31 Wanda Dalecka, Marja Wysłouchowa, 104.

32 Zofia Sokół, „Przodownica", 109. 
joznawczej. „Zorza” była miesięcznikiem adresowanym do kobiet wiejskich. Ukazująca się nakładem Wydawnictwa im. Kasyldy Kulikowskiej jako dodatek do „Przyjaciela Ludu” zwracała się do kobiet wiejskich jako żon, matek i rządnych gospodyn ${ }^{33}$.

$\mathrm{Na} ł a m a c h$ miesięcznika przeważały artykuły historyczne, ukazujące przeszłość narodu polskiego, ze szczególnym uwzględnieniem roli i udziału ludności wiejskiej w powstaniach narodowych, podkreślając ich ofiarność na rzecz narodu. Głosiło hasła solidaryzmu społecznego, którego wyrazem było zamieszczanie okazjonalnych artykułów pierwszomajowych. Maria publikowała także listy od czytelników, które kształtowały program pisma. Dział korespondencji obok artykułów historycznych zajmował najwięcej miejsca w każdym numerze. Wysłouchowa zwracała się do swoich czytelników jak do partnerów redakcyjnych, co było wyjątkiem w czasopiśmiennictwie galicyjskim. Wanda Dalecka w 1905 pisała:

„Zorza” przez trzy lata karmiła duchowo, oświecała i wzmacniała czytelników nader licznych, po całym świecie rozrzuconych .... . Mówiąc przeważnie o obowiązkach i pracy dla kraju, ma jeden cel i jedna wyraźna drogę: uszlachetnienia - i oświecenia ${ }^{34}$.

Stan zdrowia Wysłouchowej uniemożliwił dalsza pracę przy redakcji „Zorzy”. Pismo zostało zawieszone w 1902 r. Maria nie wróciła już do pracy dziennikarskiej. Zmarła 20 marca 1905 r., pozostawiając wspaniałą spuściznę publicystyczna. Na łamach konkurencyjnej „Przodownicy” ukazał się artykuł w pełni podkreślający zaangażowanie Marii w pracę na rzecz ludu: „Z każdej strony wieje szczera, serdeczna miłość do wiejskiego ludu"35.

\section{Bibliografia}

\section{Źródła}

Centralne Państwowe Historyczne Archiwum Ukrainy we Lwowie zesp. 841, inw. 1, sygn. 151, k. 1-6, zesp. 841, inw. 1, sygn. 152, k. 7-16.

33 Zofia Sokół, „Zorza Marii Wysłouchowej”, 53-70.

34 Wanda Dalecka, Marja Wysłouchowa, 63.

35 „Maria Wysłouchowa”, Przodownica, nr 4, 1905, 56-57. 


\section{Prasa}

„Przegląd Społeczny”,

„Kurier Lwowski”,

„Przodownica”,

"Tydzieñ",

„Zorza”.

\section{Opracowania}

Brock, Peter. „Maria Wysłouchowa: Wielka nauczycielka ludu polskiego", Wiadomości, R. 9, nr 39 (443), 2, 1954.

Brock, Peter. „Maria Wysłouchowa (1858-1905) and the Polish Peasant Movement in Galicia”, Canadian Slavonic Papers, nr 1, 2015, 89-102.

Dalecka, Wanda. Marja Wysłouchowa. Wspomnienie pozgonne, (Lwów: 1905).

Dunin-Wąsowicz, Krzysztof (red.), Przegląd Społeczny 1886-1887, (Wrocław: Zakład im. Ossolińskich, Wydawnictwo Polskiej Akademii Nauk, 1955).

Dunin-Wąsowicz, Krzysztof. Czasopiśmiennictwo ludowe w Galicji, (Wrocław: Wydawnictwo Zakładu Narodowego im. Ossolińskich, 1952).

Jankowski, Edmund. Eliza Orzeszkowa, (Warszawa: Państwowy Instytut Wydawniczy, 1988).

Jarowiecki, Jerzy. Studia nad prasa polska XIX i XX wieku, t. 2, (Kraków: Wydawnictwo Naukowe Akademii Pedagogicznej, 2006).

Kałwa, Dobrochna. "Ze studiów nad historią kobiet w XIX wieku. Metodologia, stan badań", Historyka, t. 27, 1997, 115-124.

Kałwa, Dobrochna, Pudłocki, Tomasz (red.), Historia zwyczajnych kobiet $i$ zwyczajnych mężczyzn: dzieje społeczne $w$ perspektywie gender, (Przemyśl: Państwowa Wyższa Szkoła Wschodnioeuropejska: Towarzystwo Przyjaciół Nauk, 2007).

Krzywicki, Ludwik. Wspomnienia, t. 1, (Warszawa: Czytelnik, 1957).

Kucharska, Zofia. „Kontakty Marii Wysłouchowej z ludnością Ślaska Cieszyńskiego", Śląski Kwartalnik Historyczny Sobótka, t. 29, nr 1, 1974, s. 67-74.

Myśliński, Jerzy. „Wysłouchowie: twórcy prasy ludowej”, Kwartalnik Historii Prasy Polskiej, R. XXX, nr 3-4, 145-152.

Paczkowski, Andrzej. „Prasa polityczna ruchu ludowego (19181939)”, (Warszawa: Państwowe Wydawnictwo Naukowe, 1970). 
Romanowiczówna, Zofia. Klaudynki. Kartki z dziejów patriotycznej pracy kobiet $w$ Galicyi, $w$ drugiej połowie ubiegłego stulecia, (Lwów: Księgarnia Gubrynowicza i syna, 1913).

Skóra, Aneta. „Rola polskiej kobiety w życiu społecznym epoki pozytywizmu w świetle opracowań, pamiętników i wspomnień", w: Krzysztof Jakubiak (red.), Partnerka, matka, opiekunka. Status kobiety w dziejach nowożytnych od XVI do XX wieku, (Bydgoszcz: Wydawnictwa Uczelniane Wyższej Szkoły Pedagogicznej, 2000).

Sokól, Zofia. „Zorza" Marii Wysłouchowej (1900-1902)”, Kwartalnik Historii Prasy Polskiej, R. XXIII, nr 3, 1984, 53-70.

Sokó1, Zofia. "„Przodownica" (1899-1912). Zarys monograficzny”, Rocznik Naukowo-Dydaktyczny WSP, z. 1: Prace Bibliotekoznawcze, 1982, 99-123.

Stapiński, Jan. Pamiętnik, (Warszawa: Ludowa Spółdzielnia Wydawnicza, 1959).

Toczek, Alfred. „Problematyka historyczna w literacko-naukowym dodatku "Kuriera Lwowskiego" - "Tydzień" (1893-1906)", Rocznik Historii Prasy Polskiej, z. 2, 2002, 78-102. 